\title{
Production of polyclonal antisera using recombinant coat proteins of Grapevine leafroll-associated virus 2 and Grapevine virus B
}

\author{
Paula Radaelli(1), Thor Vinícius Martins Fajardo(2), Osmar Nickel(2), Marcelo Eiras ${ }^{(3)}$ and Gilvan Pio-Ribeiro ${ }^{(1)}$ \\ (1)Universidade Federal Rural de Pernambuco, Departamento de Agronomia, Avenida Dom Manoel de Medeiros, s/no, Dois Irmãos, \\ CEP 52171-900 Recife, PE, Brazil. E-mail: paularadaelli@hotmail.com, gilvan@depa.ufrpe.br (2)Embrapa Uva e Vinho, Caixa Postal 130, \\ CEP 95700-000 Bento Gonçalves, RS, Brazil. E-mail: thor@cnpuv.embrapa.br, nickel@cnpuv.embrapa.br ${ }^{(3)}$ Instituto Biológico, Centro de \\ Pesquisa e Desenvolvimento de Sanidade Vegetal, Avenida Conselheiro Rodrigues Alves, no 1252, CEP 04014-002 São Paulo, SP, Brazil. \\ E-mail: eiras@biologico.sp.gov.br
}

\begin{abstract}
The objective of this work was to produce and characterize specific antisera against Brazilian isolates of Grapevine leafroll-associated virus 2 (GLRaV-2) and Grapevine virus B (GVB), developed from expressed coat proteins (CPs) in Escherichia coli, and to test their possible use for the detection of these two viruses in diseased grapevines. The coat protein (CP) genes were RT-PCR-amplified, cloned and sequenced. The CP genes were subsequently subcloned, and the recombinant plasmids were used to transform $E$. coli cells and express the coat proteins. The recombinant coat proteins were purified, and their identities were confirmed by SDS-PAGE and Western blot and used for rabbit immunizations. Antisera raised against these proteins were able to recognize the corresponding recombinant proteins in Western blots and to detect GLRaV-2 and GVB in infected grapevine tissues, by indirect ELISA, discriminating healthy and infected grapevines with absorbances $\left(\mathrm{A}_{405}\right)$ of $0.08 / 1.15$ and $0.12 / 1.30$, respectively. Expressing $\mathrm{CP}$ genes can yield high amount of viral protein with high antigenicity, and GLRaV-2 and GVB antisera obtained in this study can allow reliable virus disease diagnosis.
\end{abstract}

Index terms: Vitis, GLRaV-2, GVB, indirect ELISA, recombinant protein, Western blot.

\section{Produção de anti-soros policlonais a partir de proteínas capsidiais recombinantes de Grapevine leafroll-associated virus 2 e Grapevine virus B}

\begin{abstract}
Resumo - O objetivo deste trabalho foi produzir e caracterizar anti-soros específicos contra isolados brasileiros do Vírus do enrolamento-da-folha da videira 2 (GLRaV-2) e do Vírus B da videira (GVB), desenvolvidos a partir das proteínas capsidiais expressas em Escherichia coli, e testar seu possível uso para a detecção destes dois vírus em videiras infectadas. Os genes da proteína capsidial (CP) foram amplificados via RT-PCR, clonados e seqüenciados. Foram, subseqüentemente, subclonados, e os plasmídeos recombinantes foram empregados na transformação das células de $E$. coli e na expressão das proteínas capsidiais. As proteínas capsidiais recombinantes foram purificadas, e suas identidades foram confirmadas em SDS-PAGE e "Western blot" e utilizadas para imunizar coelhos. Os anti-soros produzidos contra essas proteínas foram capazes de reconhecer as proteínas recombinantes correspondentes em "Western blot", de detectar GLRaV-2 e GVB em tecidos infectados de videiras pelo ELISA indireto, e de discriminar videiras sadias e infectadas, com absorbâncias $\left(\mathrm{A}_{405}\right)$ de 0,08/1,15 e 0,12/1,30, respectivamente. A expressão dos genes CP pode produzir grandes quantidades de proteínas virais, com elevada antigenicidade, e os anti-soros de GLRaV-2 e GVB obtidos neste trabalho possibilitam a diagnose confiável desses vírus.
\end{abstract}

Termos para indexação: Vitis, GLRaV-2, GVB, ELISA indireto, proteína recombinante, Western blot.

\section{Introduction}

Among grapevine (Vitis spp.) viral diseases, in Brazil, grapevine leafroll and corky bark stand out due to their economic relevance (Fajardo et al., 2003).

Grapevine leafroll-associated virus 2 (GLRaV-2; genus Closterovirus, family Closteroviridae) has a positive-sense, single-stranded RNA genome of
16,494 nucleotides, with eight open reading frames (ORF), of which ORF 6 encodes the coat protein (ca. $22 \mathrm{kDa}$ ) (Abou-Ghanem et al., 1998; Meng et al., 2005; Beuve et al., 2007). GLRaV-2 is one among twelve (GLRaV-1 to -11 and WC-HSP-10) species involved in the grapevine leafroll disease complex. Detection of GLRaV-2 has been previously reported in Brazil (Kuniyuki et al., 2002). 
Infection with grapevine leafroll causes, in Vitis vinifera L., downward curling and discoloration of leaves, in the end of the growing season, and results in reduction of yield and quality of grape berries. Additionally, GLRaV-2 is also involved in the aetiology of disorders known as graft-incompatibility, young vine decline and rootstock stem lesion (Abou-GhanemSabanadzovic et al., 2000; Bertazzon \& Angelini, 2004; Beuve et al., 2007). Elimination of GLRaV-2 had beneficial impact with a marked increase in fresh fruit yield (22\%), cumulative weight growth (21\%), and sugar concentration of fruit juice $(9 \%)$ (Komar et al., 2007).

Corky bark, a component of grapevine rugose wood complex, is caused by Grapevine virus B (GVB; genus Vitivirus, family Flexiviridae) (Martelli et al., 2007), which possesses a positive single-stranded RNA genome of 7,599 nucleotides, with five ORFs, of which ORF 4 encodes the coat protein $(23 \mathrm{kDa}$ ) (Boscia et al., 1993; Minafra et al., 1994; Saldarelli et al., 1996). GVB has been reported earlier in Brazil (Kuniyuki \& Costa, 1982; Kuhn, 1992; Nickel et al., 2002).

Corky bark causes yield decreases, incomplete ripening of grapes and progressive decline and death of plants (Kuhn, 1992). Some cultivars and rootstocks are symptomless carriers or exhibit only mild symptoms, while others suffer rapid decline. Typical swelling and longitudinal bark cracks of young branches, and early drying of branches occur in $V$. labrusca cultivars. Elimination of GVB had also a beneficial impact, with an increase in vigor (35\%) and production (16\%) (Komar et al., 2007). There is experimental proof of controled transmission of GVB by several species of pseudococcid mealybugs (Boscia et al., 1993).

Antisera and several variants of enzyme-linked immunosorbent assay (ELISA) (Clark, 1981; Koenig, 1981; Barbara \& Clark, 1982) are widely used tools for the routine detection of grapevine viruses (Kuniyuki et al., 2002; Fajardo et al., 2003). However, the production of high-quality virus-specific antisera to GLRaV-2 and GVB, suitable for their large scale detection and based on virus purification procedures, faces substantial drawbacks, including complex virus infections, low yields of virus particles, presence of inhibitory compounds - such as polyphenols, tannins and polysaccharides-, narrow range and poor mechanical transmission to herbaceous hosts, contamination of antigens with host proteins (Uyemoto et al., 1997; Xu et al., 2006; Beuve et al., 2007; Fajardo et al., 2007; Ling et al., 2007), and, especially in the case of GVB, low immunogenicity (Boscia et al., 1993).

The production of virus-specific antisera using recombinant proteins from cloned virus genes expressed in Escherichia coli, which can overcome the mentioned difficulties, has been applied to produce a number of polyclonal antisera against coat protein (CP) of several grapevine viruses (Ling et al., 2000, 2007; Minafra et al., 2000; Xu et al., 2006; Fajardo et al., 2007) and nonstructural proteins (Saldarelli \& Minafra, 2000). Expressed CP genes can yield high amounts of viral protein with adequate antigenicity, thereby surpassing the already mentioned drawbacks of viral antigen purification from infected tissue, as well as contamination of antigens with plant proteins (Uyemoto et al., 1997; Ling et al., 2007).

The large number of nowadays available nucleotide sequences of GLRaV-2 (Meng et al., 2005) and GVB (Saldarelli et al., 1996; Nickel et al., 2002), associated with the last development of molecular biology techniques, have turned expressing viral genes into an extremely powerful strategy for the production of antibodies against plant viruses. Despite the development of nucleotide sequence-based detection methods, ELISA remains highly relevant for large scale identification of grapevine virus (Fajardo et al., 2003). Thus, the availability of GLRaV-2 and GVB antisera, with adequate sensitivity and specificity, will allow reliable virus disease diagnosis in grapevines from vineyards and indexing materials from virus-free clone production programs.

The objective of this study was to produce and characterize specific antisera against Brazilian isolates of GLRaV-2 and GVB, developed from CP expressed in E. coli, and to test the possible use of the raised antisera for the detection of these two viruses in diseased grapevines.

\section{Materials and Methods}

Procedures were performed according to Sambrook \& Russel (2001). The coat protein (CP) gene of GLRaV-2, isolate L/I, from grapevine cultivar LN33 ('Couderc 1613' x 'Thompson Seedless')/'Isabel', collected in São Paulo, Brazil, was amplified by RT-PCR with the oligonucleotides GLR2CP1 (5'ATGGAGTTGATGTCCGAC3', viral sense) and 
GLR2CP2 (5'TACATAACTTCCCTTCTACC3', complementary sense) (Abou-Ghanem-Sabanadzovic et al., 2000; Bertazzon \& Angelini, 2004), ligated into the pCR2.1 vector (Invitrogen), cloned in E. coli Top10 cells and sequenced (GenBank access number EU053126).

The CP gene of GVB, isolate BR1, from grapevines indexed on the indicator LN33, collected in Rio Grande do Sul, Brazil, was amplified by RT-PCR with the oligonucleotides GVB6445 (5'ATGGAAAATATATCCCGGATGG3', viral sense) and GVB7038 (5'ACTCGTCAGACAACTCTATA TC3', complementary sense) (Saldarelli et al., 1996), ligated into the pGEM-T Easy vector (Promega), cloned in E. coli JM109 cells and sequenced (GenBank access number AF438410) (Nickel et al., 2002).

One recombinant clone, containing the $\mathrm{CP}(\mathrm{rCP})$ gene of each GLRaV-2 (GLRaV-2cp, 597 bp) and GVB (GVBcp, $594 \mathrm{bp}$ ), was cultured for 8 hours at $37^{\circ} \mathrm{C}$, in LB medium with $100 \mu \mathrm{g} \mathrm{mL}^{-1}$ ampicilin (LB/ ampicilin), and the plasmid DNA was purified using the Flexi Prep kit (Amersham Biosciences), according to the manufacturer's instructions. The GLRaV-2cp and GVBcp genes were removed from the cloning plasmids, by digestion with EcoRI, and ligated to the expression vectors pRSET-A and pRSET-C (Invitrogen), respectively, previously digested with the same enzyme.

In order to confirm the correct orientation of the inserts (CP) into pRSET-A and $-\mathrm{C}$, the obtained recombinant plasmids were sequenced, $\mathrm{PCR}$ was performed using $\mathrm{T} 7$ foward primer placed in pRSET-C and complementary sense primer (GVB7038) or plasmids were digested with the restriction enzyme $(P s t \mathrm{I})$, with a unique restriction site present both in vector pRSET-A and in the CP gene of GLRaV-2.

For in vitro expression, the constructs pRSET-A/ GLRaV-2cp and pRSET-C/GVBcp were transferred to E. coli strain BL21:DE3 by heat shock, and one colony of each clone was cultivated at $37^{\circ} \mathrm{C}$ in $200 \mathrm{~mL} \mathrm{LB} /$ ampicilin, until an $\mathrm{OD}_{600}$ of approximately 0.5 , when expression was induced by addition of isopropylbeta-D-thiogalactopyranoside (IPTG) to a final concentration of $2 \mathrm{mM}$. Six hours post-induction, the bacterial cells were collected by centrifugation $(5,000 \mathrm{~g} / 10 \mathrm{~min})$ and stored at $-80^{\circ} \mathrm{C}$. Total protein extracts were obtained by resuspension in lysis buffer (50 mM Tris-HCl, 100 mM NaCl, 2 mM EDTA, pH 8), lysozyme treatment and sonication, as described by Noueiry et al. (1994). The CP extract, resuspended in $1 \mathrm{~mL}$ of $100 \mathrm{mM} \mathrm{NaHCO}$, pH 9, plus $0.5 \%$ SDS $(\mathrm{w} / \mathrm{v})$, was purified by affinity cromatography in Ni-NTA columns (Qiagen), according to the manufacturer's instructions. GLRaV-2cp and GVBcp expressions were evaluated by $4 \% / 12 \%$ discontinuous polyacrylamide gel electrophoresis (SDS-PAGE) and Western blot, using commercial antisera against the CPs of GLRaV-2 (Sanofi-Pasteur) or GVB (Agritest), respectively, and antibodies against the six histidine tag (anti-his C-terminal/AP Ab) (Invitrogen). The protein quantification was done by comparing one aliquot of GLRaV-2 or GVB expressed CP with serial dilution aliquots of BSA $\left(0.25,0.5,1,1.4,2\right.$ and $2.5 \mathrm{mg} \mathrm{mL}^{-1}$ BSA) in SDS-PAGE, since Bradford reagent was incompatible with the SDS concentration present in recombinant protein solutions.

After dialysis in $10 \mathrm{mM}$ phosphate buffer, $\mathrm{pH} 7.4$, plus $0.425 \% \mathrm{NaCl}(\mathrm{w} / \mathrm{v}), 180,250,400,500$ and $670 \mu \mathrm{g}$ of the in vitro-expressed denatured protein were injected intramuscularly into the hind legs of a white, New Zealand rabbit, approximately 35 days old, at weekly intervals. One rabbit was used for each expressed CP. The first injection was performed with complete Freund's adjuvant $(1: 1 \mathrm{v} / \mathrm{v})$, and the four remaining injections with incomplete Freund's adjuvant $(1: 1 \mathrm{v} / \mathrm{v})$. Beginning one week after the last injection, seven weekly bleedings were carried out $(25-30 \mathrm{~mL}$ bleeding by animal). Blood samples were allowed to coagulate for 1 hour at $37^{\circ} \mathrm{C}$, and $30 \mathrm{~min}$ at $4^{\circ} \mathrm{C}$, and then centrifuged at $3,000 \mathrm{~g} / 10 \mathrm{~min}$. The antisera were aliquoted and stored at $-20^{\circ} \mathrm{C}$.

Western blot tests were performed to confirm the effective production and specificity of antibodies against GLRaV-2 and GVB expressed CP. Aliquots $(2 \mu \mathrm{L})$ of these proteins were eletrophoresed in $12 \%$ SDS-PAGE gels and transferred onto a nitrocellulose membrane using a wet blotter (BioRad). The membrane was blocked ( $2 \% \mathrm{w} / \mathrm{v}$ powdered milk), incubated with crude GLRaV-2 and GVB antisera (1:250 v/v), washed, incubated with goat-anti-rabbit antibodies-AP conjugate (Sigma), and revealed with NBT/BCIP as substrate.

Purification of the globuline fraction ( $\operatorname{IgG}$ ) from the antisera was carried out by ion exchange chromatography, in a DEAE-sephacel resin (Sigma) equilibrated with $25 \mathrm{mM}$ sodium acetate buffer, $\mathrm{pH}$ 5.2, 
and the antisera was diluted 1:10 (v/v) in distilled water. An equal volume of saturated ammonium sulphate was used to precipitate proteins in antisera. The suspension was centrifuged at $3,000 \mathrm{~g} / 10 \mathrm{~min}$, the pellet was resuspended in $2 \mathrm{~mL}$ of half-strength PBS and dialysed for 12 hours at $4^{\circ} \mathrm{C}$ in the same buffer. Globuline fractions were quantified at $280 \mathrm{~nm}$ and stored at $-20^{\circ} \mathrm{C}$.

Plate-trapped antigen-ELISA (PTA-ELISA), a type of indirect ELISA (Clark, 1981), was performed by using purified IgG produced against rCP of GLRaV-2 and GVB (at $4 \mu \mathrm{g} \mu \mathrm{L}^{-1}$ ) and general conjugate (at 1:1,000 v/v) (goat-anti-rabbit antibodies-alkaline phosphatase conjugate, Sigma). This allowed evaluating the specificity and sensitivity of the obtained antisera against GLRaV-2 and GVB, in order to detect these viruses in grapevines previously tested positive for them. The samples, consisting of leaf veins and petioles of six GLRaV-2-infected grapevines and six GVB-infected grapevines, were powdered in the presence of liquid nitrogen and diluted $1: 3(\mathrm{w} / \mathrm{v})$ in coating buffer (50 mM sodium carbonate, $\mathrm{pH} 9.6)$. Samples were considered infected, when absorbance at $405 \mathrm{~nm}$ was at least twice the average value of the healthy controls.

\section{Results and Discussion}

Expressions of GLRaV-2cpand GVBcp were induced four times each in $200 \mathrm{~mL}$ cultures, resulting in 0.750 , $3.125,0.750$ and $0.875 \mathrm{mg} \mathrm{CP}$ of GLRaV-2 (a total of $5.5 \mathrm{mg}$ ) and $0.750,1.625,0.875$ and $1.250 \mathrm{mg} \mathrm{CP}$ of GVB (a total of $4.5 \mathrm{mg}$ ). Compared to other results (Ling et al., 2000, 2007; Fajardo et al., 2007) on fusion protein expressions, the average protein yields obtained in the present study $\left(6.875\right.$ and $5.625 \mu \mathrm{g} \mathrm{mL}^{-1}$ culture medium of GLRaV-2cp and GVBcp, respectively) are in the range of similar studies and adequate for the required schedule of rabbit immunizations.

In SDS-PAGE gels, the presence of bands with a molecular mass corresponding to approximately 25 and $26 \mathrm{kDa}$ (expected values for GLRaV-2 and GVB fusion proteins, respectively) was observed (Figure 1). Of these values, ca. 22 and $23 \mathrm{kDa}$ corresponded to the CPs of GLRaV-2 and GVB, respectively, increased by approximately $3 \mathrm{kDa}$ of six histidine fused to the $\mathrm{N}$-terminal of these proteins (6 His-tag). The band corresponding to the fusion protein was absent in the sample transformed with the empty vector.
The identities of the expressed proteins were confirmed by Western blot, using commercial antisera against the CP of GLRaV-2 or GVB, and antibodies against the 6 His-tag (Figure 2).

Testing the produced antisera for the detection of expressed GLRaV-2 and GVB CPs by Western blot revealed that they reacted strongly and specifically to the homologous immunogens (Figure 3), which demonstrates the effectiveness of the immunization procedure, as well as the immunogenicity of the fusion protein.

The purified IgG were obtained in concentrations of 1,396 and $2,010 \mu \mathrm{g} \mathrm{mL}^{-1}$ for GLRaV-2 and GVB, respectively. Their excellent recognition of GLRaV-2 and GVB in infected grapevines was confirmed by PTA-ELISA (Table 1). Neither of the antisera showed relevant absorbance with healthy samples, which demonstrates high sensitivity and specificity (Tables 1 and 2). Considering absorbance value range, obtained as a result of routine indexing tests performed in the lab, the performance of GLRaV-2 and GVB produced antisera was similar to that obtained with commercial antibodies. PTA-ELISA was chosen to check the antisera, because of its low cost, reliability and

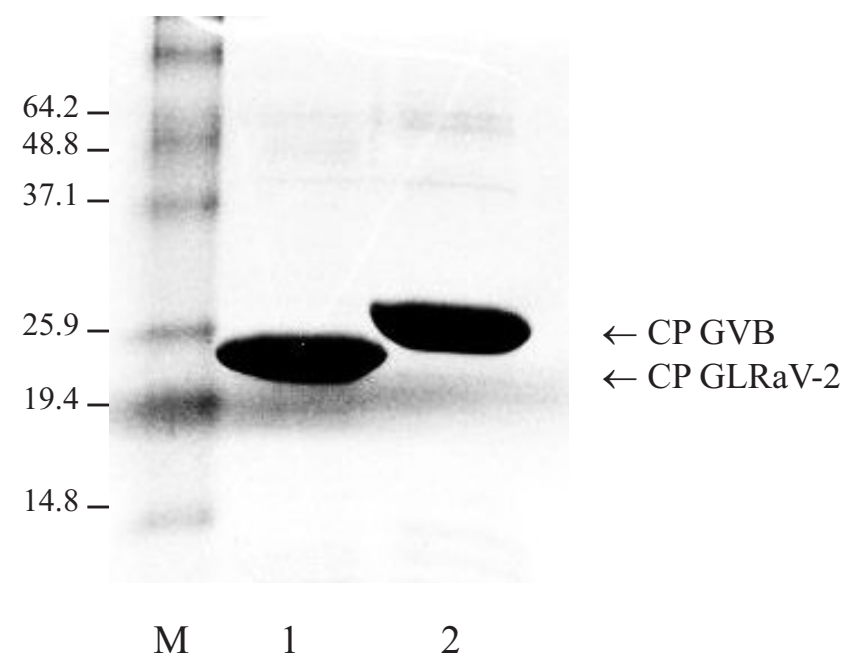

Figure 1. SDS-polyacrylamide gel electrophoresis, 12\% (p/v), stained with Coomassie Blue. Lanes 1 and 2 represent aliquots $(10 \mu \mathrm{L})$ of fractions of total protein extracts from Escherichia coli, transformed with the constructs pRSET-A/ GLRaV-2cp and pRSET-C/GVBcp, respectively, collected from Ni-NTA-column. M, molecular mass markers $(\mathrm{kDa})$. Arrows at right indicate the position of the fusion proteins. 
practicability as a large scale virus diagnostic method (Ling et al., 2000). Also indirect ELISA variants showed to yield a broader specificity in heterologous reactions and were reliably sensitive, thus are more suitable for large scale analyses (Koenig, 1981; Barbara \& Clark, 1982).

Differences observed in the nucleotide or amino acids sequences of the CP gene may have an effect on all protein functions, including the serological relationship. Therefore, the $\mathrm{CP}$ gene variability should be considered, since some epitopes of the coat protein are the basis for antibody recognition by ELISA. It was demonstrated that GLRaV-2 and GVB Brazilian isolates show $94-98 \%$ and $82 \%$ nucleotide identities, respectively, with foreign isolates from different geographic origins (Nickel et al., 2002). Thus, it is reasonable to assume that antisera produced in this study could not recognize all foreign isolates or strains,

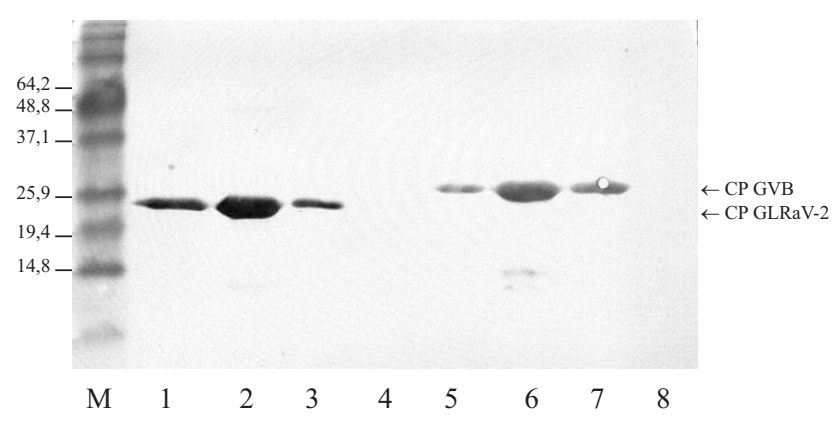

Figure 2. Western blot with commercial antisera against the six-histidine tag (anti-his C-terminal/AP Ab) (Invitrogen, $1: 2,000 \mathrm{v} / \mathrm{v})$. Lanes 1 to 3 represent aliquots $(5 \mu \mathrm{L})$ of sequential fractions of total protein extracts from Escherichia coli, transformed with the construct pRSET-A/ GLRaV-2cp; lanes 5 to 7 are pRSET-C/GVBcp, collected from Ni-NTA-column; and lanes 4 and 8 are aliquots $(5 \mu \mathrm{L})$ of the control extracts containing the empty expression vector pRSET-C (negative controls). M, molecular mass markers $(\mathrm{kDa})$. Arrows at right indicate the position of the fusion proteins. and vice-versa, highlighting the importance of antisera production against local isolates. GLRaV-2 occurs in nature as a number of biological and molecular variants, grouped into distinct strains, based on their CP gene sequences, such as PN (= Sem, 94/970), 93/955, H4, RG, Alfie and BD (Bertazzon \& Angelini, 2004; Meng et al., 2005). A similar observation was done with GVB (Shi et al., 2004). Despite this fact, the antisera against GLRaV-2, isolate L/I, produced in this study, reacted positively to several GLRaV-2 isolates, including five GLRaV-2 isolates (Table 2), which showed among them $87-99 \%$ and $90-99 \%$ of nucleotide and deduced amino acids identities, respectively, in the coat protein gene, according to nucleotide sequences at GenBank (http://www.ncbi.nlm.nih.gov). Similar results were

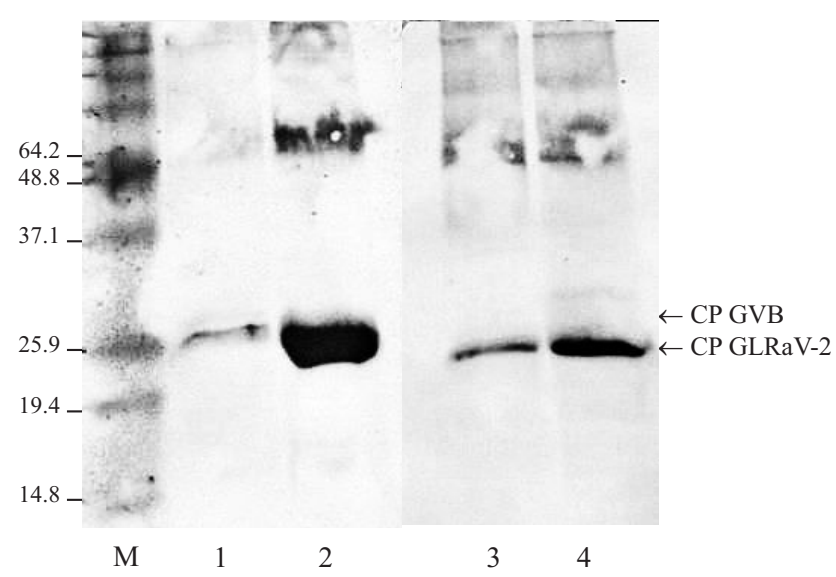

Figure 3. Western blot with GVB (lanes 1 and 2) and GLRaV-2 (lanes 3 and 4) obtained antisera $(1: 250 \mathrm{v} / \mathrm{v})$, at third bleeding, against the fusion proteins expressed in Escherichia coli. Lanes 1 and 2 are aliquots $(2 \mu \mathrm{L})$ of purified GVB CP from different expressions and aliquots of total protein collected from Ni-NTA-column, and lanes 3 and 4 are purified GLRaV-2 CP from different expressions and aliquots of total protein collected from Ni-NTA-column. $\mathrm{M}$, molecular mass markers $(\mathrm{kDa})$. The arrows at right indicate the GVB and GLRaV-2 fusion proteins.

Table 1. Absorbance values at $405 \mathrm{~nm}$, observed in a plate-trapped antigen-ELISA using grapevine (Vitis spp.) samples and antisera against GLRaV-2 and GVB fusion proteins, expressed in Escherichia coli cells. Conditions: IgG at $4 \mu \mathrm{g} \mathrm{mL} \mathrm{mL}^{-1}$ and conjugate at 1:1000(v/v).

\begin{tabular}{lcc}
\hline Sample & \multicolumn{2}{c}{ Absorbance at 405 nm } \\
\cline { 2 - 3 } & GLRaV-2 (Time to reading 1 hour 55 min) & GVB (Time to reading 55 min) \\
\hline Healthy grapevine [cv. Rupestris du Lot (1:3 w/v) or Agritest extract] & 0.08 & 0.12 \\
GLRaV-2-infected grapevine cv. Riesling (SC 1545) (1:3 w/v) & - & - \\
GVB-infected grapevine cv. LN33 (1:3 w/v) & - & 1.30 \\
GVB-infected grapevine (Agritest grapevine extract) & - & 1.10 \\
\hline
\end{tabular}


Table 2. Absorbance values at $405 \mathrm{~nm}$, observed in a plate-trapped antigen-ELISA using grapevine (Vitis spp.) samples $(1: 3 \mathrm{w} / \mathrm{v})$ infected with six GLRaV-2 isolates and antisera against GLRaV-2, isolate L/I, fusion protein, expressed in Escherichia coli cells. Conditions: IgG at $4 \mu \mathrm{g} \mathrm{mL} \mathrm{m}^{-1}$ and conjugate at 1:1,000 (v/v).

\begin{tabular}{|c|c|c|c|}
\hline Sample & Isolate & Collected site & $\begin{array}{c}\text { Absorbance at } 405 \mathrm{~nm} \\
\text { GLRaV-2 (Time to reading } 1 \text { hour } 55 \mathrm{~min} \text { ) }\end{array}$ \\
\hline Healthy grapevine cv. Rupestris du Lot & - & Bento Gonçalves, RS & 0.15 \\
\hline $\begin{array}{l}\text { GLRaV-2-infected grapevine cv. Mission/Concord }(08.2710)^{(1)} \\
\text { (EU053125) }^{(2)}\end{array}$ & $\mathrm{M} / \mathrm{C}$ & São Roque, SP & 0.75 \\
\hline $\begin{array}{l}\text { GLRaV-2-infected grapevine cv. LN33/Isabel (17.960) } \\
\text { (EU053126) }\end{array}$ & $\mathrm{L} / \mathrm{I}$ & São Roque, SP & 0.96 \\
\hline $\begin{array}{l}\text { GLRaV-2-infected grapevine cv. Seibel } 2 \text { (CB 73-11) } \\
\text { (EU204909) }\end{array}$ & SE & São Roque, SP & 0.57 \\
\hline GLRaV-2-infected grapevine cv. Itália (CB 1115) (EU204910) & IT & Capão Bonito, SP & 1.13 \\
\hline $\begin{array}{l}\text { GLRaV-2-infected grapevine cv. Moscatel de Hamburgo (JD } \\
\text { 1451) (EU204911) }\end{array}$ & $\mathrm{MH}$ & Jundiaí, SP & 0.64 \\
\hline $\begin{array}{l}\text { GLRaV-2-infected grapevine cv. Riesling (SC 1545) } \\
\text { (EU204912) }\end{array}$ & RI & Videira, SC & 0.42 \\
\hline
\end{tabular}

${ }^{(1)}$ Annotated code of grapevine in plant collection of IAC, Campinas, SP. ${ }^{(2)}$ GLRaV-2 nucleotide access code at GenBank (http://www.ncbi.nlm.nih.gov).

obtained, using the produced antiserum against GVB, isolate BR1, to detect the virus in other GVB-infected grapevines, but, in this case, the variability of GVB isolates was not molecularly characterized as GLRaV-2. These results show that the produced antisera reliably detected several molecularly different isolates of GLRaV-2 (Table 2), as well as GVB, in six different infected grapevine accesses of unknown origin.

The variable viral titer, in GLRaV-2-infected grapevine plants, was demonstrated in two indirect ELISA tests, spaced one and a half month from each other. In the first test, the absorbance value of GLRaV-2-infected grapevine cultivar Riesling was 1.15 , and in the second one it was 0.42 , considering precisely the same experimental conditions (Tables 1 and 2). The titer fluctuation is well known of many grapevine viruses and determines when, how and where the sample to be analysed must be collected to perform serological tests (Fajardo et al., 2003).

The present results confirm previous reports stating the suitability of antisera obtained against recombinant $\mathrm{CP}$ for detection of viruses by serological tests $(\mathrm{Xu}$ et al., 2006; Ling et al., 2007), including indirect ELISA.

\section{Conclusions}

1. Antigens of GLRaV-2 and GVB can be conveniently obtained by gene expression in bacteria.

2. Expressing CP genes can yield high amounts of viral protein with high antigenicity, and surpass the drawbacks of viral antigen purification from infected tissue, as well as contamination of antigens with plant proteins.
3. The GLRaV-2 and GVB antisera, produced against two specific isolates, are able to detect a range of distinct isolates of these viruses by indirect ELISA.

4. The availability of GLRaV-2 and GVB antisera with high sensitivity and specificity, such as those obtained in this study, can allow reliable virus disease diagnosis.

\section{Acknowledgements}

To Conselho Nacional de Desenvolvimento Científico e Tecnológico, for financing the project; to Marcos F. Vanni, for technical support; to Dr. Hugo Kuniyuki (IAC, Campinas, SP), for supplying the GLRaV-2 isolates.

\section{References}

ABOU GHANEM-SABANADZOVIC, N.; SABANADZOVIC, S.; CASTELLANO, M.A.; BOSCIA, D.; MARTELLI, G.P. Properties of a new isolate of Grapevine leafroll-associated virus 2 . Vitis, v.39, p.119-121, 2000.

ABOU-GHANEM, N.; SABANADZOVIC, S.; MINAFRA, A.; SALDARELLI, P.; MARTELLI, G.P. Some properties of Grapevine leafroll-associated virus 2 and molecular organization of the 3 ' region of the viral genome. Journal of Plant Pathology, v.80, p.37-46, 1998.

BARBARA, D.J.; CLARK, M.F. A simple indirect ELISA using $\mathrm{F}(\mathrm{ab})_{2}$ fragments of immunoglobulin. Journal of General Virology, v.58, p.315-322, 1982.

BERTAZZON, N.; ANGELINI, E. Advances in the detection of Grapevine leafroll-associated virus 2 variants. Journal of Plant Pathology, v.86, p.283-290, 2004.

BEUVE, M.; SEMPÉ, L.; LEMAIRE, O. A sensitive one-step real-time RT-PCR method for detecting Grapevine leafroll- 
associated virus 2 variants in grapevine. Journal of Virological Methods, v.141, p.117-124, 2007.

BOSCIA, D.; SAVINO, V.; MINAFRA, A.; NAMBA, S.; ELICIO, V.; CASTELLANO, M.A.; GONSALVES, D.; MARTELLI, G.P. Properties of a filamentous virus isolated from grapevines affected by corky bark. Archives of Virology, v.130, p.109-120, 1993.

CLARK, M.F. Immunosorbent assays in plant pathology. Annual Review of Phytopathology, v.19, p.83-106, 1981.

FAJARDO, T.V.M.; BARROS, D.R.; NICKEL, O.; KUHN, G.B.; ZERBINI, F.M. Expression of Grapevine leafroll-associated virus 3 coat protein gene in Escherichia coli and production of polyclonal antibodies. Fitopatologia Brasileira, v.32, p.496-500, 2007.

FAJARDO, T.V.M.; KUHN, G.B.; NICKEL, O. Doenças virais. In: FAJARDO, T.V.M. (Ed.). Uva para processamento: fitossanidade. Brasília: Embrapa Informação Tecnológica, 2003. p.45-62. (Embrapa Informação Tecnológica. Frutas do Brasil, 35).

KOENIG, R. Indirect ELISA methods for the broad specificity detection of plant viruses. Journal of General Virology, v.55, p.53-62, 1981.

KOMAR, V.; EMMANUELLE, V.; DEMANGEAT, G.; FUCHS, M. Beneficial effect of selective virus elimination on the performance of Vitis vinifera cv. Chardonnay. American Journal of Enology and Viticulture, v.58, p.202-210, 2007.

KUHN, G.B. Intumescimento dos ramos da videira ("corky bark"), doença constatada no Rio Grande do Sul. Fitopatologia Brasileira, v.17, p.399-406, 1992.

KUNIYUKI, H.; COSTA, A.S. Estudos sobre a virose fendilhamento cortical da videira em São Paulo. Fitopatologia Brasileira, v.7, p.71-78, 1982.

KUNIYUKI, H.; REZENDE, J.A.M.; SCAGLIUSI, S.M.M.; VEGA, J.; YUKI, V.A. Incidência de Grapevine leafroll-associated virus 1,2 e 3 em vinhedos do Estado de São Paulo. Summa Phytopathologica, v.28, p.311-314, 2002.

LING, K.S.; ZHU, H.Y.; JIANG, Z.Y.; GONSALVES, D. Effective application of DAS-ELISA for detection of grapevine leafroll associated closterovirus- 3 using a polyclonal antiserum developed from recombinant coat protein. European Journal of Plant Pathology, v.106, p.301-309, 2000.

LING, K.S.; ZHU, H.Y.; PETROVIC, N.; GONSALVES, D. Serological detection of Grapevine leafroll virus 2 using an antiserum developed against the recombinant coat protein. Journal of Phytopathology, v.155, p.65-69, 2007.
MARTELLI, G.P.; ADAMS, M.J.; KREUZE, J.F.; DOLJA, V.V. Family Flexiviridae: a case study in virion and genome plasticity. Annual Review of Phytopathology, v.45, p.73-100, 2007.

MENG, B.; LIN, C.; GOSZCZYNSKI, D.E.; GONSALVES, D. Genome sequences and structures of two biologically distinct strains of Grapevine leafroll-associated virus 2 and sequence analysis. Virus Genes, v.31, p.31-41, 2005.

MINAFRA, A.; CASATI, P.; ELICIO, V.; ROWHANI, A.; SALDARELLI, P.; SAVINO, V.; MARTELLI, G.P. Serological detection of Grapevine rupestris stem pitting-associated virus (GRSPaV) by a polyclonal antiserum to recombinant virus coat protein. Vitis, v.39, p.115-118, 2000.

MINAFRA, A.; SALDARELLI, P.; GRIECO, F.; MARTELLI, G.P. Nucleotide sequence of the 3' terminal region of the RNA of two filamentous grapevine viruses. Archives of Virology, v.137, p.249-261, 1994.

NICKEL, O.; FAJARDO, T.V.M.; ARAGÃO, F.J.L.; CHAGAS, C.M.; KUHN, G.B. Detection and coat protein gene characterization of an isolate of Grapevine virus B from corky bark-affected grapevines in Southern Brazil. Fitopatologia Brasileira, v.27, p.279-284, 2002.

NOUEIRY, A.O.; LUCAS, W.J.; GILBERTSON, R.L. Two proteins of a plant DNA virus coordinate nuclear and plasmodesmal transport. Cell, v.76, p.925-932, 1994.

SALDARELLI, P.; MINAFRA, A. Immunodetection of the $20 \mathrm{kDa}$ protein encoded by ORF 2 of Grapevine virus B. Journal of Plant Pathology, v.82, p.157-158, 2000.

SALDARELLI, P.; MINAFRA, A.; MARTELLI, G.P. The nucleotide sequence and genomic organization of grapevine virus B. Journal of General Virology, v.77, p.2645-2652, 1996.

SAMBROOK, J.; RUSSELL, D. Molecular cloning: a laboratory manual. $3^{\text {rd }}$ ed. New York: CSHL Press, 2001. 999p.

SHI, B.J.; HABILI, N.; GAFNY, R.; SYMONS, R.H. Extensive variation of sequence within isolates of Grapevine virus $B$. Virus Genes, v.29, p.279-285, 2004.

UYEMOTO, J.K.; KRAG, C.R.; ROWHANI, A. An improved purification procedure for grapevine leafroll associated viruses. American Journal of Enology and Viticulture, v.48, p.521-524, 1997.

XU, Z.Y.; HONG, N.; XING, B.; WANG, G.P. Partial molecular characterization of a Chinese isolate of Grapevine leafrollassociated virus 2 and production of antisera to recombinant viral proteins. Journal of Plant Pathology, v.88, p.89-94, 2006.

Received on July 7, 2008 and accepted on September 10, 2008 